\title{
SHARAFIYYA COMPLEX IN BIDLIS: RETHINKING OF LOCAL HISTORY IN ISLAMIC ARCHITECTURE
}

\section{Birgül AÇIKYILDIZ ŞENGÜL*}

\begin{abstract}
This article aims to discuss the architectural and decorative characteristics of the Sharafiyya Complex in Bidlis in its historical and geographical context. The complex was commissioned by Emîr Sharaf ibn Emîr Shams al-Dîn al-Roşkî, a member of the Kurdish Bidlis dynasty, in 935/1528-29. Emîr Sharaf Beg ruled Bidlis from 909/1504 to 940/1533. His son Shams al-Dîn Beg completed the complex by constructing a mausoleum for his father in 940/1533 after his death. The monumental complex was built during his alliance with the Ottomans when he governed his territory without the interference of the Ottoman Empire. The complex is formed of a mosque, a mausoleum, a zawiya, a fountain, a madrasa with a covered market, a qaysâriyya (bazaar) and a bath-house. Emîr Sharaf Beg endowed villages, arable lands, several shops, markets, a hammam and a flourishing mill to fund the complex. The article will first provide a brief historical background to the Bidlis dynasty during the reign of Emîr Sharaf Beg (909/1504-940/1533). Then it will describe and analyze the monuments forming the complex, and examine main features of the architecture of Sharafiyya Complex.
\end{abstract}

Keywords: Islamic architecture, Kurdish architecture, Bidlis, Emîr Sharaf Beg alRoşkî.

\section{BITTLISS ŞEREFIYE KÜLLIYESİ: İSLAM SANATINDA YEREL TARIHİ YENIDEN DÜŞÜNMEK}

Öz

$\mathrm{Bu}$ makale, Bitlis'te bulunan Şerefiye Külliyesi'nin mimari ve süsleme özelliklerini tarihi ve coğrafi bağlamında tartışmayı amaçlamaktadır. Kompleks, H. 935/M. 1528-29 yılında Kürt Bitlis Beyliği'ne mensup Emîr Şeref ibn Emîr Şems el-Dîn el-Roşkî tarafından inşa ettirilmiştir. Emîr Şeref Beg, 909/1504'ten 940/1533'e kadar Bidlis'i yönetmiştir. Oğlu Şems el-Dîn Beg, Emîr Şeref Beg'in ölümünden sonra 940/1533'te babasına bir türbe inşa ederek külliyeyi tamamlamıştır. Bu anıtsal kompleks, Emîr Şeref Beg'in Osmanlı İmparatorluğu ile

Makale Gönderim Tarihi: 05.07.2018, Kabul Tarihi: 31.07.2018

Doi: 10.26791/sarkiat.441105

* Dr, Univ Paul Valéry Montpellier 3, CRISES EA 4424, F34000, Montpellier, Fransa / Fransız Anadolu Araştırmaları Enstitüsü (IFEA), İstanbul. birgul@acikyildiz.com, ORCID: 0000-00034891-4875 
ittifakta olduğu ama Osmanlı'nın müdahalesi olmaksızın topraklarını bağımsız olarak yönettiği dönemde inşa edilmiştir. Külliye, cami, türbe, zaviye, çeşme, kapalı çarşı, medrese, kayseriye ve hamamdan oluşmaktadır. Emîr Seref Beg, kompleksi inşa ettirmek ve yaşatmak için çok sayıda köy, tarıma elverişli toprak, dükkan, hamam ve değirmen vakf etmiştir. Makalede ilk olarak Bitlis Beyliği'nin Emîr Seref Beg (909/ 1504-940/1533) dönemi hakkında kısa bir tarihi arka plan sunulduktan sonar kompleksi oluşturan yapılar betimlenerek ve analiz edilerek Şerefiye Külliyesi'nin mimari özellikleri ortaya konulacaktır.

Anahtar Kelimeler: İslam mimarisi, Kürt mimarisi, Bitlis, Emîr Seref Beg elRoşkî.

\section{Introduction}

This article explores the Sharafiyya Complex's architectural features within its historical and geographical context. The complex is located at the confluence of the Ribât and Kuchûr streams in the city centre of Bidlis. ${ }^{1}$ The complex consists of several institutions: a mosque, a mausoleum, a zawiya, ${ }^{2}$ a fountain, a madrasa with a covered market, a qaysâriyya (bazaar) and a bath-house. ${ }^{3}$ The complex was commissioned by Emîr Sharaf ibn Emîr Shams al-Dîn al-Roşkî, a member of the Kurdish Bidlis dynasty, in 935/1528-29. The mausoleum located next to the mosque was built by Emîr Shams al-Dîn ibn Emîr Sharaf in 940/1533 for his father, ${ }^{4}$ who was killed in Safer 940 (August-September 1533). ${ }^{5}$ The buildings are lined up neatly along the right bank of the Kuchûr stream. An associated bath-

\footnotetext{
${ }^{1}$ Bidlis is a city located to the west of Lake Van in eastern Turkey and populated mostly by the Kurds. A river flows through the city and divaricates into two channels. The river is better known as Bitlis stream today.

${ }^{2}$ Sharafhan Bidlisî, the ruler of Bidlis (r. 1578-1597), the grandson of Emîr Sharaf Beg and the author of Sharafnâma, names the monument as zawiya (Sharafhan Bidlisî 1870, II/I: 215). Yet seventeenth century Turkish traveler, Evliyâ Çelebi refers to an 'imaret (soup-kitchen) (Evliyâ Çelebi 2012: 172). The Bidlis Shari’a Court Records (Şeriyye Sicilleri) also mention about Sharafiyya Zawiya (Başı 2015: 53-54; Uluçay 2006: 224, 226) but never Sharafiyya 'Imaret. Thus, I will consider the building as a zawiya.

${ }^{3}$ Besides this standing building composing the complex, Evliyâ Çelebi pointed to the existence of a primary school (sibyan mektebi) named Sharaf Khan Mektebi and a khan named Sharaf Khan's Khan (Evliyâ Çelebi 2012: 132-133). Furthermore, Sharafhan Bidlisî states that Sharaf Beg built a big two storey khan with other buildings in his complex, called Sharafiyya (Sharafhan Bidlisî 1870, II/1: 320). The British traveler Lynch, visited the site in 1893, describes the khan to be with a fine doorway, adorned with the figures of two snarling lions (Lynch 1901: 155). A caravanserai is also mentioned in the pious foundation list of Sharafiyya Mosque and Madrasa in the Ottoman tax register (Tahrir defteri) dated 1540 (Altunay 1994: 109-110). The Sharafiyya Khan does not exist anymore. However, the ruins of a khan located near Great Mosque corresponds to the description of Lynch. The khan with a door to two snarling lions is called Ruined Khan today (Baş1 2015: 63). It might be the khan commissioned by Emîr Sharaf Beg. Moreover, Lynch mentions about a stone bridge crossing the river next to the mosque (Lynch 1901: 155) which was demolished and a concrete bridge was erected instead. Nineteenth century gravures also show the existence of the stone bridge (Cassell's Illustrated Family Paper 1854: 172).

${ }^{4}$ Sharafhan Bidlisî gives different information about the construction of the mausoleum in his book. According to him, Emîr Sharaf Beg designated the location of his mausoleum next to the mosque while he was alive and his wife Shah Beygi Khatun, the daughter of Alî Beg of Sason, built a big dome to cover his tomb (Sharafhan Bidlisî 1870, II/I: 320).

5 The inscription on his tombstone gives this date, read by Pektaş (2001, 42-43).
} 
house, named Khan Hammam, is at a short distance away, located at the left bank of the Ribât stream. [Fig. 1]

Scholars have addressed main features of the Sharafiyya complex's structure and decoration in their works in the course of the last thirty years. ${ }^{6}$ Although they all agreed on the name of the founder as Emîr Sharaf Beg and the date as 935/152829 for the construction of the complex because of the written evidence of the inscription that the monument itself provides, they have not discoursed on Emîr Sharaf Beg's identity and his dynasty's status. But rather the complex like other monuments of the dynasty in Bidlis was considered either Seljukid or Ottoman and they are claimed to represent Seljukid (Ar1k 1971: 118; Goodwin 1971: 309; Baş 2002: 69) or Ottoman manner (Uluçam 2002: 320) without giving any substantial evidence.

By referring to historical sources such as the sixteenth century text, Sharafhan Bidlisî's Sharafnâma, a seventeenth century travel account of Evliyâ Çelebi and the inscriptions on the monuments, this article will argue that the complex was constructed by the Kurdish ruler of Bidlis. It will also discuss the legal status of the Bidlis dynasty during the Ottoman hegemony in the sixteenth century and correct the common misconception in the literature about the complex that it is Seljukid or Ottoman. Kurdish dynasties contributed to Islamic art and architecture since the tenth century with the foundation of the Marwanid Dynasty (990-1096) and ruled a large area between Armenia, Turkey, Iran, Iraq, and Syria. ${ }^{7}$ However, as the Kurds do not have a modern national state, researchers ignored Kurdish material cultures or attributed them to the Turks, Arabs or Persians because of religious commonality.

The article will first provide a brief historical background to the Bidlis dynasty during the reign of Emîr Sharaf Beg (909/1504-940/1533). Then it will describe and analyze the monuments forming the complex; finally, it will examine the main features of the architecture of the Sharafiyya Complex.

\section{Bidlis Dynasty During the Reign of Emîr Sharaf Beg (909/1504-940/1533)}

The foundation inscription located at the gate at the entrance to the courtyard states that it was built in the year 935/1528-29 by Emîr Sharaf Beg al-Roşkî, one of the most influential and powerful rulers of the Bidlis dynasty who allied with the Ottomans in 921/1515 and ruled a large area between Bidlis, Mush, Hinis and

\footnotetext{
${ }^{6}$ The main studies on the complex include Arık 1971 and Baş 2002. Book chapters were also written by Goodwin 1971, Erken 1977, Sinclair 1987 and Uluçam 2002.

${ }^{7}$ Other well-known Kurdish dynasties are Shaddadîs in Ani, Dvin, Gence (951-1198), Buyids in Ray, and Baghdad (934-1062), Ayyubids in Hasankeyf, Syria, Palestine, and Egypt (1171-1496), Azizans in Jazirat (1262-1847), Hakkariya dynasty (12th century-1849), Mahmudî dynasty in Khoshâb (1397-1870), Ardalan dynasty in Sanandaj (1169-1867), Soranî dynasty in Arbil (10th century-1835), Baban dynasty in Suleimania (1649-1850), and other many smaller principalities scattered all over the region (Muhammed Emin Zeki Beg 2010; Sharafhan Bidlisî 1870).
} 
Hakkarî independently. ${ }^{8}$ As for the mausoleum, its foundation inscriptions certify that it was commissioned by Emîr Shams al-Dîn ibn Emîr Sharaf Beg in 940/1533-34 who sought refuge in the Safavid court after his father's death. Like his father, he received the khan title from Shah Tahmasb and was appointed to privileged positions until his death in 965/1557-58 (Sharafhan Bidlisî 1870, II/I: 329).

Historical sources date the genealogy of the Kurdish princes of Bidlis to the Sasanian dynasty and consider them to be descendants of Khosrow I (Nushirwân in Kurdish and Persian) (Sharafhan Bidlisî 1870, II/I: 233). ${ }^{9}$ Despite the extreme political instability of the region, the princes of the dynasty ruled Bidlis and its environs autonomously from the mid-ninth century to the end of the nineteenth century. They allied with the powers of the region or opposed them according to their interests during their long history. The begs of Bidlis especially benefited from their alliance with the Qara Qoyunlu Turcomans in the fifteenth century but lost their autonomy during the dominance of the Seljukids (1139-1181), Aq Qoyunlu Turcomans (1469-1498), and Ottomans (1533-1578/1870-). The Bidlis princes asserted their hegemony over Bidlis by minting coinages and reciting Friday sermons in their names and founding religious, charitable, and social institutions such as mosques, madrasas, khanqahs, zawiyas, qaysâriyyas, mental hospitals (bimarhanes), hospitals (dar al-shifas), caravansaries, bath-houses, bridges, stables, workplaces and workshops in Bidlis and other towns ruled by them (Sharafhan Bidlisî 1870, II: 215, 254, 262).

Emîr Sharaf Beg became the ruler of Bidlis, succeeding his cousin Emîr Ibrahim. In the early years of his sovereignty, he was imprisoned with other Kurdish begs of the region by Shah Ismail, which caused him and other begs to seek another alliance. After his liberation, Emîr Sharaf Beg gathered other Kurdish begs of the region and agreed to ally with the Ottoman state. A treaty between Ottoman Sultan Selim I and the Kurdish begs was signed in 921/1515, and they recognized Ottoman authority. In return, they were nominated by the Ottoman administration as the rulers of the region that they were occupying hereditarily in the newly established sub-province (sancak) system (Öz 2003: 145). Emîr Sharaf Beg was renominated as the ruler of Bidlis and its districts.

The hükûmet-ocaklık administrative system was applied to Bidlis in 921/1515, which allowed Emîr Sharaf Beg to govern his territory without the interference of the Ottoman Empire. Bidlis was not under timar system. The revenues were not entered in the Sultanic register (tahrir). Thus, Emîr Sharaf Beg held whole earnings of the district (Evliyâ Çelebi 2012: 128; Öz 2003: 146). The districts of Bidlis were not under supervision and authority of the Ottoman officials. Sharaf

\footnotetext{
${ }^{8}$ His strongholds were namely Bidlis, Akhtamar, Ahlat, Mush, Hinis, Kifnedur, Amurk, Kelhoz, Firuz, Silîm, Gulhar, Tatir, Pasin, Avnîk, and Malazgird.

9 The dynasty is also known as Diyadin and Sharafhanî dynasties and composed of the Roşkî (Rojikî) tribe.
} 
Beg had the right to collect taxes and had juridical power. He did not have any legal obligation to the Ottoman Empire apart from his allegiance (Sinclair 2003: 2) which required that he had to enter the military service of the Ottoman military administrator, the Beylerbeyi of Diyarbakir, during the expeditions against the enemies of the Ottoman Empire (Evliyâ Çelebi 2012: 128; Kodaman 1986: 21). Yet, the autonomous status of Bidlis changed in 938/1531 when Ulâme Tekelu, the Safavid governor of Azerbaijan, defected to the Ottomans in 937/1530. Emîr Sharaf Beg was charged by the Ottoman state to convey him to Istanbul. When Ulâme Tekelu arrived in Istanbul, he defamed Sharaf Beg to ally with Shah Tahmasb and asked to capture Bidlis and appoint him as its ruler. Thereupon, Ulâme Tekelu was sent to Diyarbekir to serve as governor and capture Bidlis, and Emîr Sharaf Beg was dismissed from his post. Right afterwards Sharaf Beg asked for support from Shah Tahmasb who responded positively and sent his troops to fight against the Ottoman army. Emîr Sharaf Beg lost his life in the battle in 940/1533, and Sultan Sulaimân Qânûnî seized Bidlis. Emîr Sham al-Dîn, the son of Emîr Sharaf Beg, sought refuge in the Safavid court. Consequently, Bidlis was ruled as an ordinary sancak between 938/1531-986/1579 and subjected to the tax census (tahrir). Villages in Bidlis were changed to grants (timar). The sancak begs were appointed from elsewhere (Sinclair 2003: 124) until Emîr Sharafhan Bidlisî, the grandson of Emîr Sharaf Beg and the son of Emîr Shams al-Dîn, received an investiture decree of the governorate of the Bidlis province in 986/1579 by the Ottoman Sultan Murad III (r. 1574-1595). From this time on, the princes of Bidlis owned their privileged autonomous dynasty status until 1870 which ended with the application of a more centralized administration system by the Ottomans in the region (Kodaman 1986: 14). [Fig. 2]

\section{The Architecture of the Complex}

The Sharafiyya Complex is composed of several buildings, set within three locations. The first is formed by the mosque, the mausoleum, the zawiya, the minaret and the fountain, which share a central courtyard and are entered through an elaborate gate. The second group is comprised of the madrasa, the covered market and the qaysâriyya, built adjacent to each other in a row sharing common walls, entered individually, and located behind the mosque. The third is only a single building, the bath-house, constructed to yield revenue for the complex institution, located on the opposite side of the river. They are all built of brown and grey limestone (küfeki). Brick was only used in the interior of the domes, the squinches and the mihrab in the prayer room and the zawiya. [Fig. 3]

The elaborately ornamented entrance portal, located in the eastern corner of the mosque and the south of the mausoleum, leads to a small vestibule, then to the portico entrance of the mosque and opens into a rectangular court. The projecting portal is set within a rectangular frame. Interlacing star and octagonal patterns 
decorate the frame but remain unfinished at the top (Sinclair 1971: 301). ${ }^{10}$ The doorway is formed by a tri-lobed muqarnas-hooded portal, articulated with fluted engaged columns topped with floral decorated capitals. An inscription band goes around three sides of the portal, an eight-foiled rosette is inscribed with the words "Emîr Sharaf Beg ordered the construction of the mosque in 935/1528-29" in thuluth script. [Fig. 4]

The court is flanked on the north by the zawiya and the minaret, on the west by the retaining wall where is also an iwan for the fountain, ${ }^{11}$ and on the south by the mosque with a five-domed portico entrance. The arches of the portico entrance, carried by the columns with plain capitals, are all pointed arch. A plain semicircular mihrab niche is in the center of the wall and two windows lie next to it. The lintel of the windows are ornamented with interlaced eight-pointed star patterns. The window is flanked with a four-row muqarnas design and framed by two engaged columns topped with floral decorated capitals. Two plain rectangular doors with flat arches, located symmetrically on the eastern and western parts of the northern wall, lead to the interior of the mosque. [Fig. 5]

The prayer hall has a rectangular plan with three rectangular aisles, parallel to the qibla but unusually short. A huge dome in front of the mihrab takes two of the aisles. Its hypostyle plan with three aisles and big dome in front of the mihrab is a widely used plan in the region, but its long walls are shortened and a more centralized interior is created here. The reason of its shortness might be the lack of space on the site, which is bordered by rocks on the west and the river on the east. The rest of the ceiling is topped with small domes and pointed vaults. The mihrab niche in brick has also lost its original features due to a bad restoration work in the 1990s. The mihrab formed a pentagon plan with a pointed arch, flanked by a rectangular frame, decorated with elaborate stuccos. Its projection outside is also pentagon. A stone inscription panel above the mihrab frame is the only original element of the mihrab remaining today. Arrk saw and photographed the original mihrab in 1971. In this image, the traces of the stucco decoration are still visible (Arık 1971: f. 43-44). According to him, stucco and glazed tile might have used to decorate the mihrab (Arik 1971: 22). Apart from the mihrab, the interior is unadorned but the windows were decorated externally with rich stone carvings. [Fig. 6]

The singlestory mausoleum is attached to the mosque with an intermediate vestibule and communicates with it by means of a window. The mausoleum is rectangular in its interior but square in its exterior. This deliberate execution was meant to separate its pyramidal dome from the vestibule and render it freestanding position. A square space was created in the interior with the application of a large arch in the south, and the center of the interior was moved to the north. The square

\footnotetext{
${ }^{10}$ Unfinished part of the decoration was completed during the restoration works in the 1990s.

11 The fountain is not in use today. The iwan of fountain serves to home two sarcophagus dating 20th century.
} 
space is covered with a high dome which was surmounted by an eight-sided pyramidal cone. Stone tombstones belong to Emîr Sharaf Beg, and five of his family members are situated in the mausoleum. Sharaf Beg's elaborately carved tomb stela bears the signature of the master Ahmad ibn Hussein of Ahlat. Intense interlaced vegetal and geometrical motifs and inscriptions decorate his stela. A mosque lamp hanging by a chain from the niche hood is placed in the center of the headstone and a pointed arch with octagon and eight-pointed star patterns is on the footstone. Upper parts are designed with interlaced palmettes, rumis, flowers and branches, and inscriptions. Similar stela forms with similar patterns are found in the Kurdish, Turkish and Armenian cemeteries located in the towns and villages located around the Lake Van.

The zawiya faces the mosque at the opposite side of the court. An iwan shaped entrance with pointed arch leads the interior. The zawiya, bigger size than the mosque, has a quatrefoil-plan which is unique but became a reference to the later 'imaret buildings in the region such as Husrev Pasha 'Imaret in Van (974/1567). Its eastern and western arms are longer and contain a rectangular vaulted room in each corner. The middle part is covered with a dome resting on a low octagonal drum. Naqshbandî Sufi sheikhs used the zawiya to perform their religious activities. Concurrently it was intended to feed travelers, religious students, teachers, and the poor. [Fig. 7]

Elaborate stone-carved façades of the minaret adjoin the zawiya imposingly, contrasting with the zawiya, which is unadorned. The cylindrical shaft on a cubicle base is divided into three sections by the bands of moldings and adorned differently. The summit of the minaret is marked by a pyramidal conic dome. The lower part of the shaft is filled with elaborately carved cartouches. Square, rectangular, circular and teardrop shaped rosettes are carved with skillful geometrical and floral patterns similar to the ones on the eastern façade of the mosque. [Fig. 8]

The madrasa, located at the back of the mosque, shares the narrow road with it and is a rectangular shape. It is a variation of the madrasa plan with an open courtyard to two iwans, surrounded in the east and west by square domed chambers for students and teachers. It is arranged symmetrically. An iwan shaped entrance similar to the gate of the zawiya leads to the court. Four rectangular vestibules were created on either side of the pointed arched iwans to enter the rooms. Its open courtyard is covered now by a hipped roof. It is not used as madrasa anymore and is in a bad state of repair. The madrasa was intended to serve for the teaching of Shafi'i doctrine. Very famous and distinguished lectures (muderris) such as Mulla Khizr Khizanî gave classes in the madrasa in Kurdish, although the text books were generally in Arabic. According to Sharafhan Bidlisî, Mulla Khizr Khizanî had no equal in the science that deals with fundamental principles and practical consequences of the jurisprudence Shafi'i, in the knowledge of exegesis and the oral law (hadîtz) (Sarafhan Bidlisî 1870, II/1: 216). The ground floor of the madrasa at the east houses five shops as a row. Pointed 
vaulted and arched shops and the shops of the qaysâriyya are still served with their original functions. [Fig. 9]

The public bath, the Khan Hammam is one of the several hammams in Bidlis, still in regular use today. It is composed of cold, warm and hot rooms topped by domes and vaults in different sizes. Its plan is similar to the hammams of different principalities of Anatolia such as Shaddadîs (951-1198), Artukids (1102-1409), Ayyubids (1185-1496) and etc. The square planned cold room is entered by a small vestibule and leads to a corridor, which extends to the warm room, restroom and the masjid. The hot room is in the northwest part of the building and in cruciform plan with square, rectangular, and L shaped private rooms in the corners. This room, with an elaborate design, is the focal point of the compound. Another important feature of the building is the masjid room entered directly from the hot room. The Khan Hammam is visible from the outside only due to the large dome surmounting the cold room and its eastern wall. [Fig. 10]

\section{Conclusion}

The Sharafiyya Complex has a standard institutional configuration and architectural typology of the Islamic world. The mosque-madrasa-zawiya type of complex was built by the Islamic states to develop cities over the centuries. The princes of Bidlis followed this tradition and erected several complexes and individual buildings in the city, which form a distinctive style of architecture. Sharafiyya Complex, connected with this tradition, is the most monumental, the most imposing, and the best-preserved building complex in Bidlis. Emîr Sharaf Beg built his complex when he was ruling Bidlis independently within the hükûmet-ocaklık administrative system. It was completed just before their alliance with the Ottomans ended in 1533. There is no Ottoman influence on the complex, which displays the features of the distinctive style of Bidlis with elaborated stonemasonry. However, its monumentality and regular arrangement suggest that Emîr Sharaf Beg has seen the Ottoman imperial monuments in Istanbul and was influenced to erect his own sovereign buildings in his capital of Bidlis to demonstrate his power on his people who were composed of Kurds and Armenians, his enemies, and his alliance, the Ottomans.

The complex is formed by a mosque, a zawiya with a minaret, a mausoleum, a fountain, a madrasa, a market, a qaysâriyya, a khan, a hammam, a primary school, and a bridge. Emîr Sharaf Beg endowed villages, arable lands, several shops, markets, a hammam, and a flourishing mill to fund the complex (Sharafhan Bidlisî 1870, II/I: 320). However, the primary school, the khan and the bridge do not exist anymore. The mosque maintained the traditional hypostyle-mosque planning arrangement with a five-domed portico entrance. The mausoleum is very typical in form in northern Mesopotamia with its cubical form and pyramidal dome. The madrasa represents an open courtyard plan with two iwans, which is also a widespread type in the region. Yet the zawiya has an unusual form for its function. The circular minaret on a cubic base is common in Bidlis and has 
similarities to the Ayyubid minarets of Hasankeyf. Intricate arabesque stone carvings were executed on the façades of the mosque, the minaret and the mausoleum. Foliated thuluth calligraphy has been used in the mosque and mausoleum inscriptions.

The inscription on the tomb stela of Emîr Sharaf Beg gives the name of the master, Ahmad ibn Hussein of Ahlat. However, the architects and stone masons of the complex are unknown to us due to lack of written evidence. Further research needs to be carried out on the subject.

\section{References}

ALTUNAY, E., 1540 (H.947) Tarihli Tahrir Defterine Göre Bitlis Sancă̆l, Ondokuz Mayıs University Unpublished MA Thesis, Samsun 1994.

ARIK, O., Bitlis Yapılarında Selçuklu Rönesansı. Ankara: Selçuklu Tarih ve Medeniyeti Enstitüsü, 1971.

BAŞ, G., Bitlis’deki Mimari Yapılarda Süsleme, Bitlis: BitlisValiliği, 2002.

BAŞI, H., "Şer’iyye Sicili Kayıtlarına Göre Bitlis Vakıfları ve Vakıf Eserleri (1878-1910)", Bitlis Eren Üniversitesi Sosyal Bilimler Enstitüsü Dergisi, 4/1 (2015): 47-60.

CASSELL, J., Cassell's Illustrated Family Paper, Vol. I. London 1854.

DEMİ, A., "16. Yüzyılda Safevî ve Osmanlı Hakimiyetinde Arşiv Belgeleri Işığında Bitlis Beyleri", Pages 253-283. I. Uluslararası Dünden Bugüne Tatvan ve Çevresi Sempozyumu Bildirileri, İstanbul: Beyan Yayınları, 2008.

ERKEN, S., Bitlis. Türkiye'de Vakif Abideler ve Eski Eserler II: 131-149. Ankara: Vakıflar Genel Müdürlüğü Yayınları, 1977.

GOODWIN, G., A History of Ottoman Architecture, London: Thames and Hudson, 1971.

ELIYÂ ÇELEBİ, Günümüz Türkçesiyle Evliyâ Çelebi Seyahatnâmesi,. 4/1. Istanbul: Yapı Kredi Yayınları, 2012.

KODAMAN, B., Osmanlı Devrinde Doğu Anadolu'nun İârî Durumu, Ankara, 1986.

LYNCH, H. F. B., Armenia, Travels and Studies (volume 2), New York and Bombay: Longmans, Green, and Co., 1901.

MUHAMMED EMIN ZEKİ BEG, Kürtler ve Kürdistan Tarihi, İstanbul: Nûbihar, 2010.

ÖZ, M., "Ottoman Provincial Administration in Eastern and Southeastern Anatolia: The Case of Bidlis in the Sixteenth Century", pages 145-56 in K. H. Karpat \& R. W. Zens (eds.), Ottoman Borderlands: Issues, Personalities and Political Changes. Madison: University of Wisconsin, 2003. 
PEKTAŞ, K., Bitlis Tarihî Mezarlıkları ve Mezar Taşları, Ankara: T.C. Kültür Bakanlığı Yayınları, 2001.

SEVGEN, N., Doğu ve Güneydoğu Anadolu'daki Türk Beylikleri, Ankara: Türk Kültürünü Araştırma Enstitüsü, 1982.

SHARAF KHAN BİDLİSI, Chèref-nâmeh ou fastes de la nation kourde (volume II/I), trans. F. B. Charmoy, St. Petersburg, 1870.

SINCLAIR, T., "The Ottoman Arrangements for the Tribal Principalities of the Lake Van Region of the Sixteenth Century", pages 110-144 in K. H. Karpat \& R. W. Zens (eds.), Ottoman Borderlands: Issues, Personalities and Political Changes, Madison: University of Wisconsin, 2003.

SINCLAIR, T. A., Eastern Turkey: An Architectural and Archaeological Survey (volume I), London: The Pindar Press, 1987.

TUNCER, O. C., Anadolu Kümbetleri: Beylikler ve Osmanl ıDönemi (volume III), Ankara: Güven Matbaası, 1992.

ULUÇAY, S., 412 Numaralı Bitlis Şer’iyye Sicili'nin Transkripsiyonu ve Değerlendirmesi (H. 1306-1308/M.1889-1891), Van Yüzüncü Y1l University Unpublished MA Thesis, Van, 2006.

ULUÇAM, A., Ortaçağ ve Sonrasında Van Gölü Çevresi Mimarlı̆̆ı -II- Bitlis, Ankara: T.C. Kültür Bakanlığı Yayınları, 2002. 


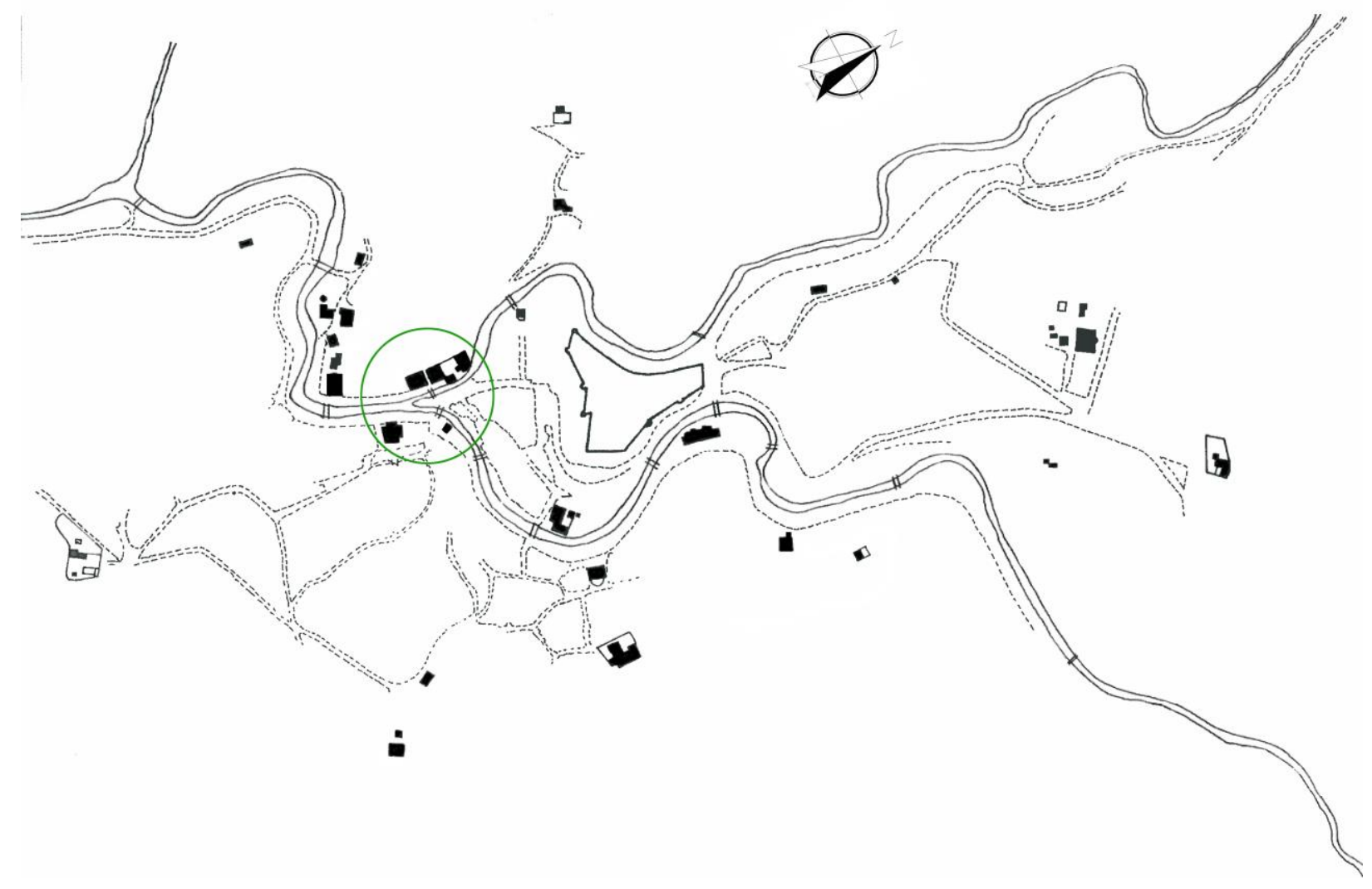

Figure 1: Map of Bidlis and its monuments (From Arık 1971: 124).
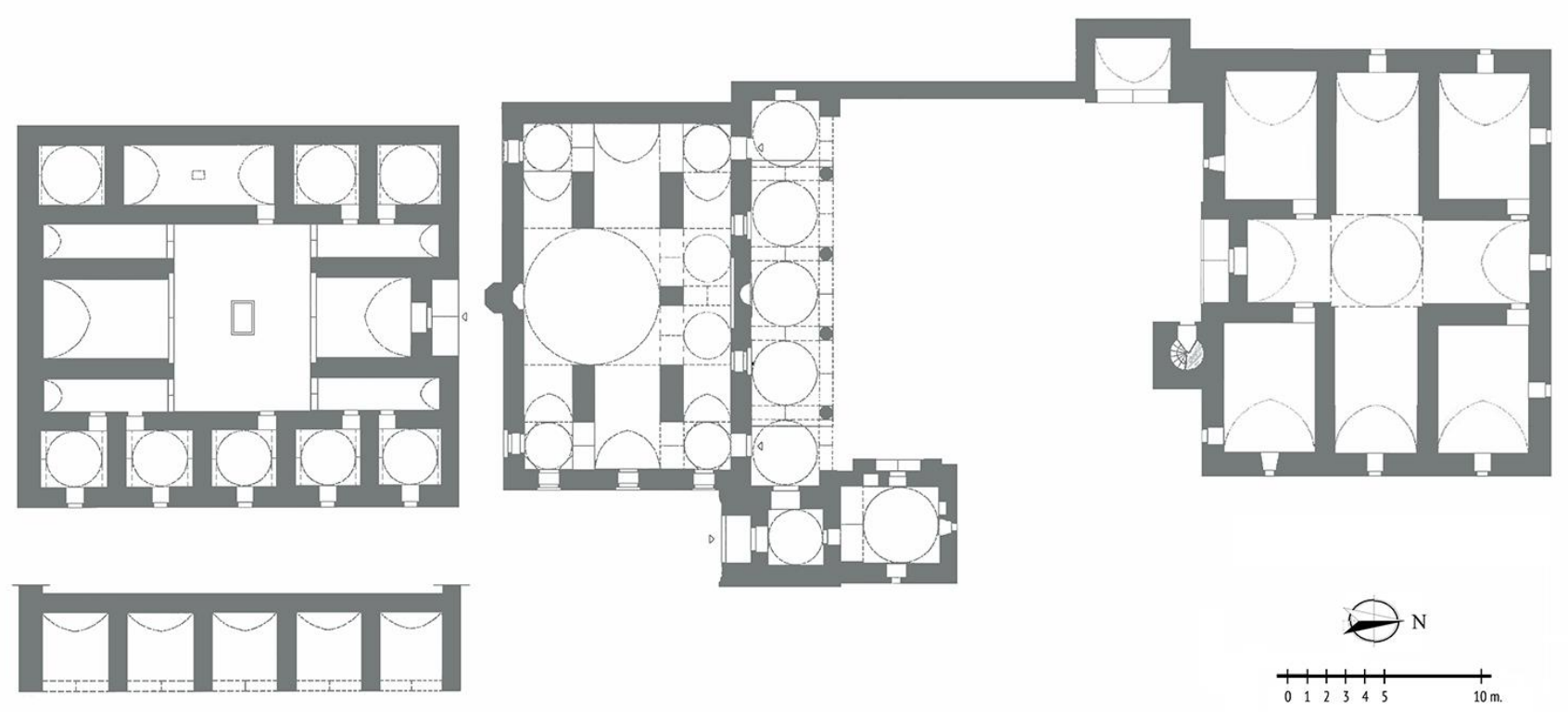

Figure 2: Plan of the complex (From Arık 1971: fig. 4). 

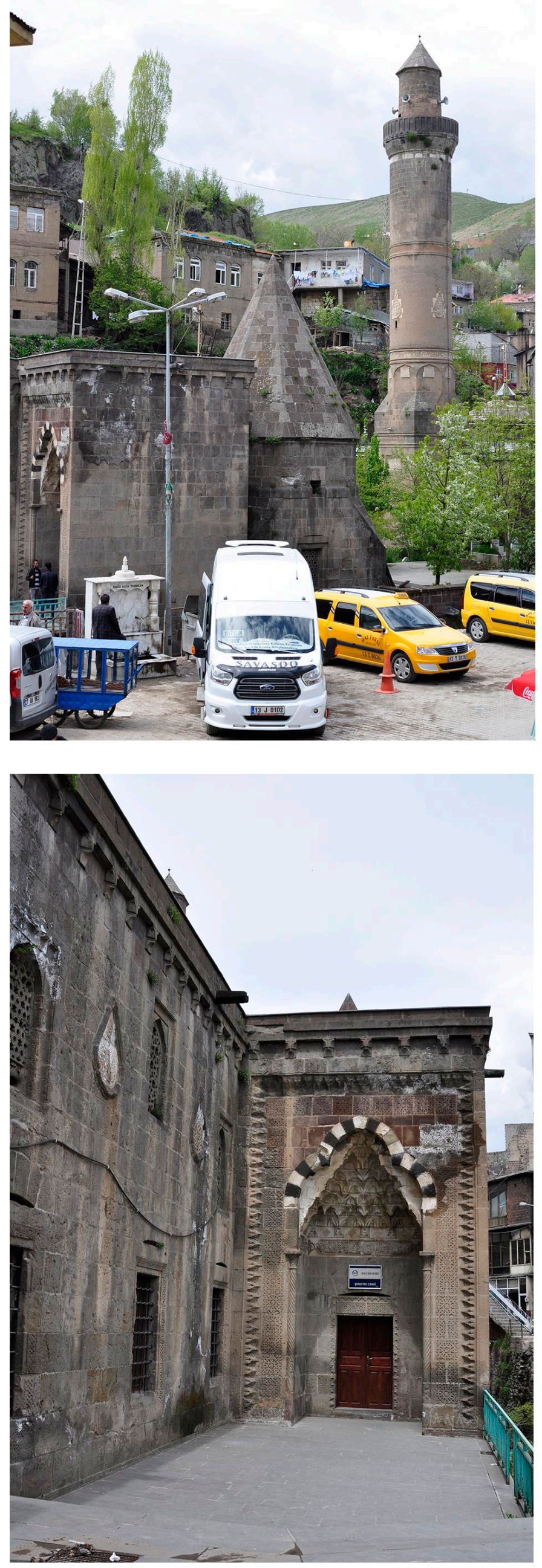

Figure 3: Eastern façade of the entrance, the mausoleum and the minaret.

Figure 4: Etrance portal and eastern façade of the mosque. 


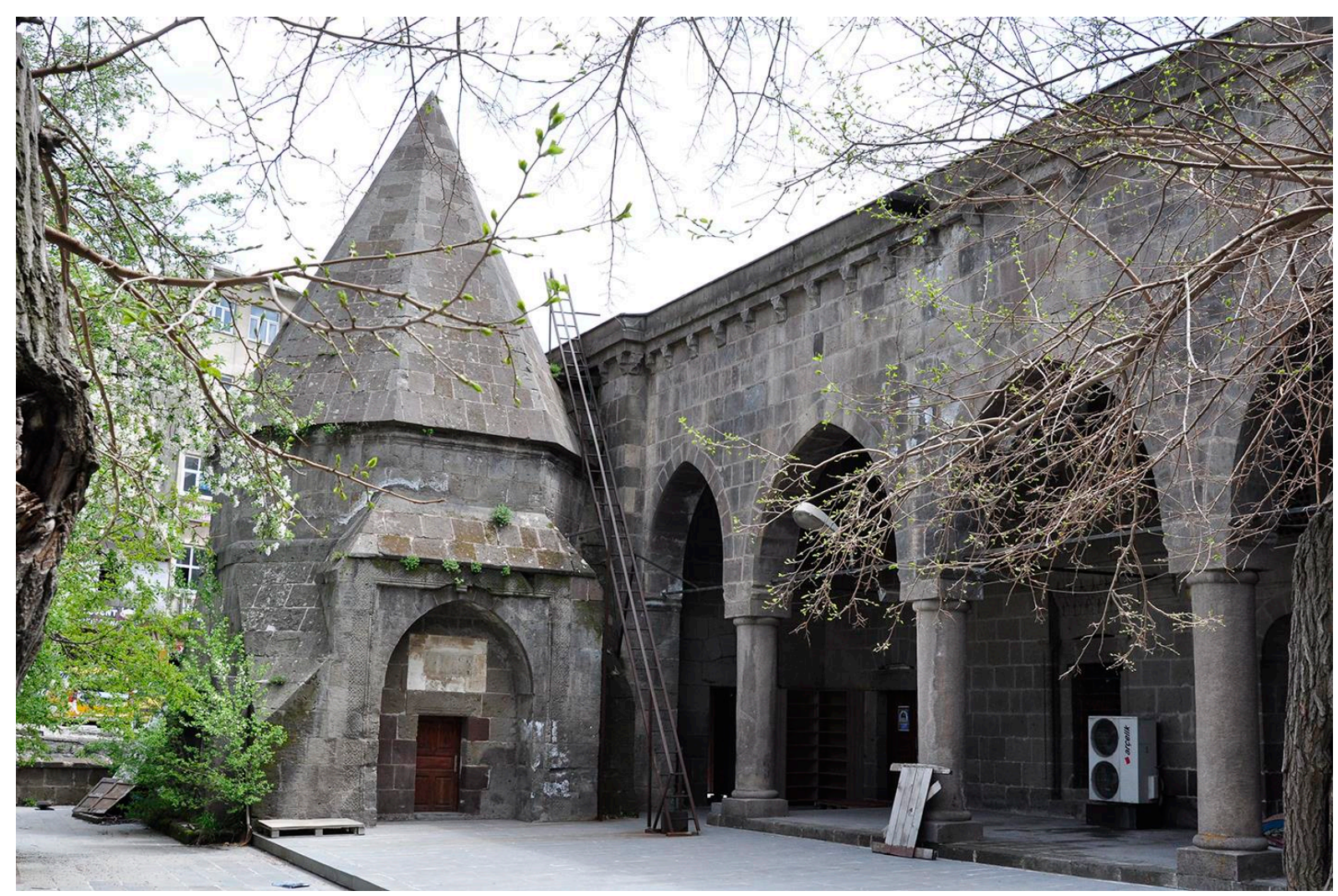

Figure 5: Mausoleum and the arched portico entrance of the mosque.

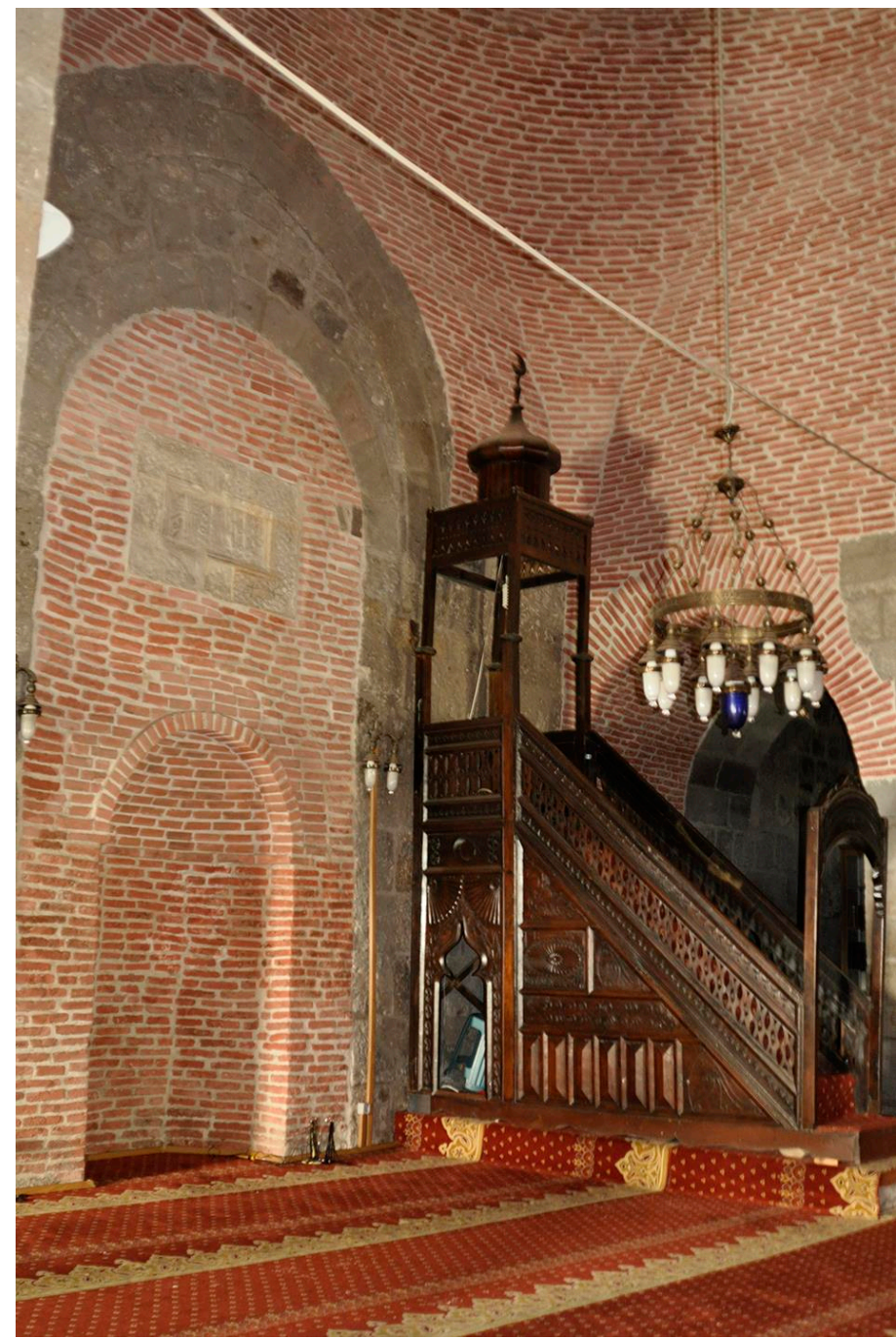

Figure 6: Interior of the mosque. Mihrab and minbar. 


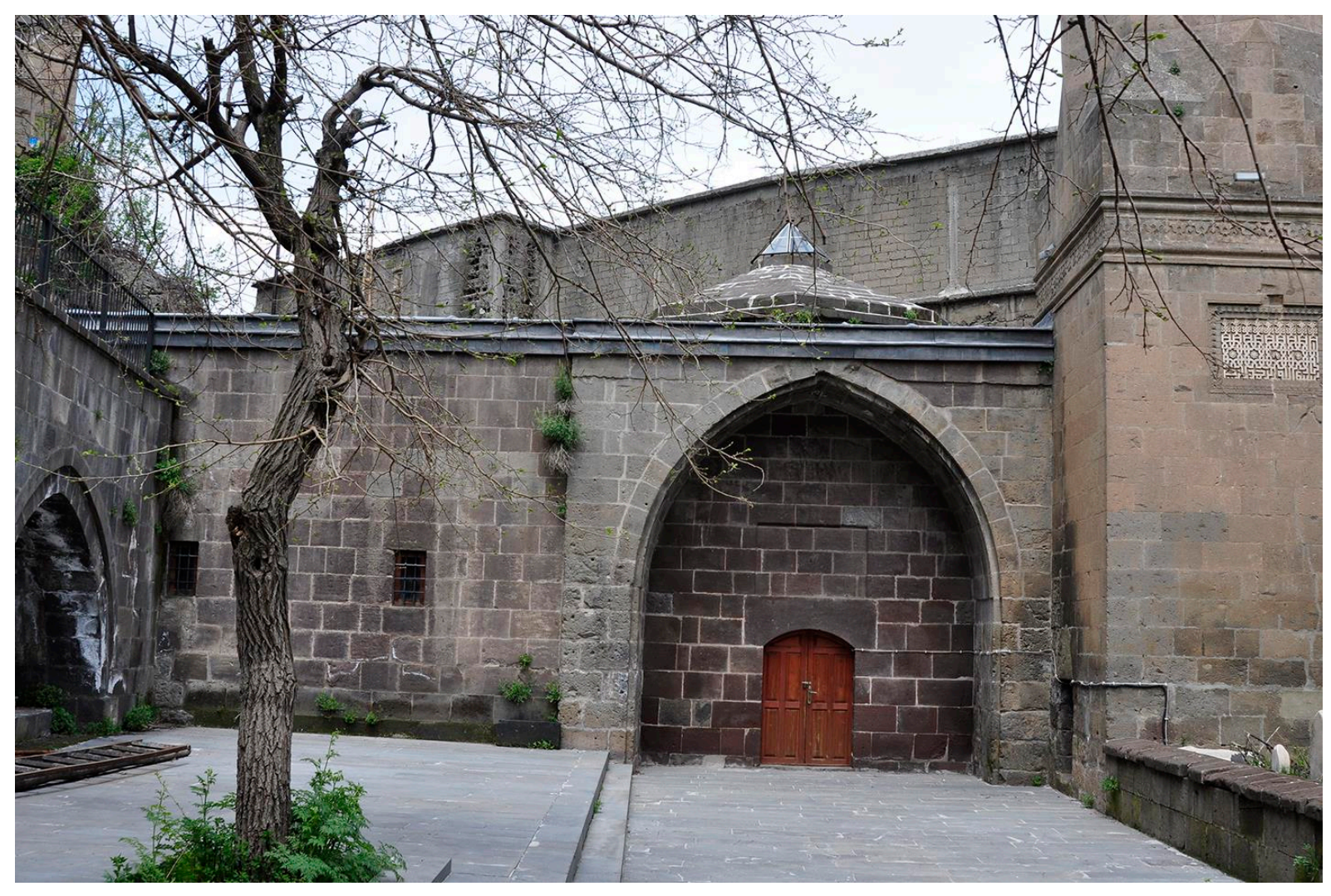

Figure 7: Entrance façade of the zawiya, the fountain iwan and the base of minaret.

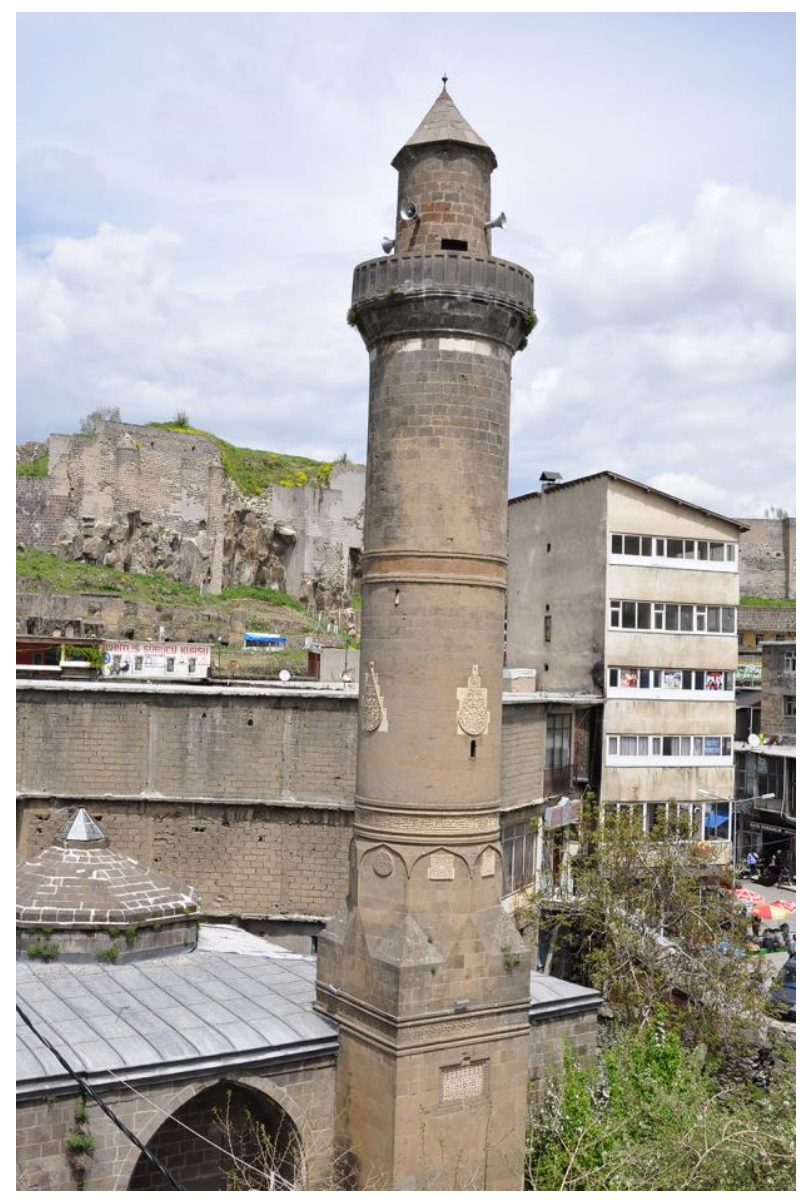

Figure 8: Minaret. 


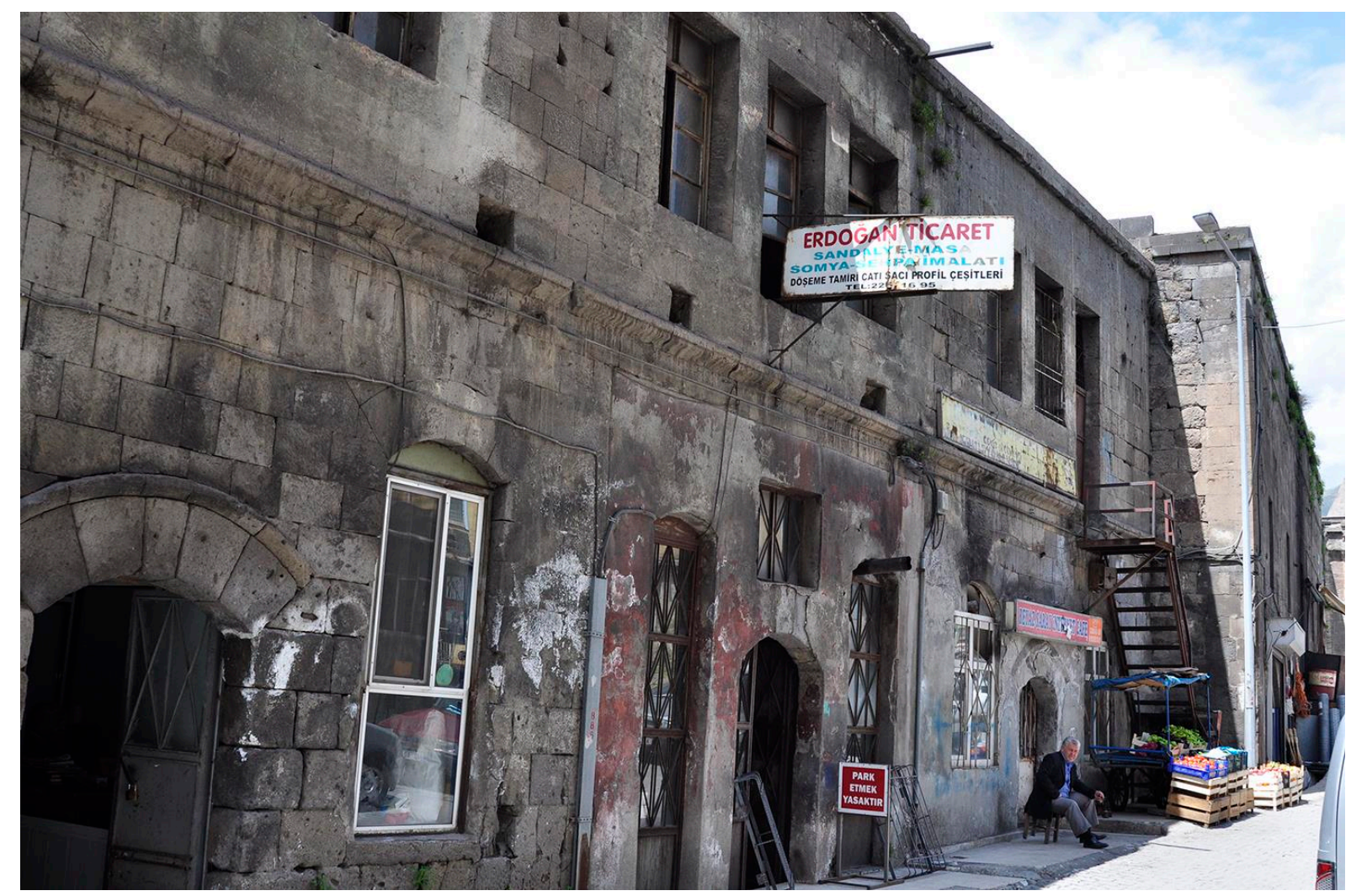

Figure 9: Eastern façade of the qaysâriyya and madrasa.
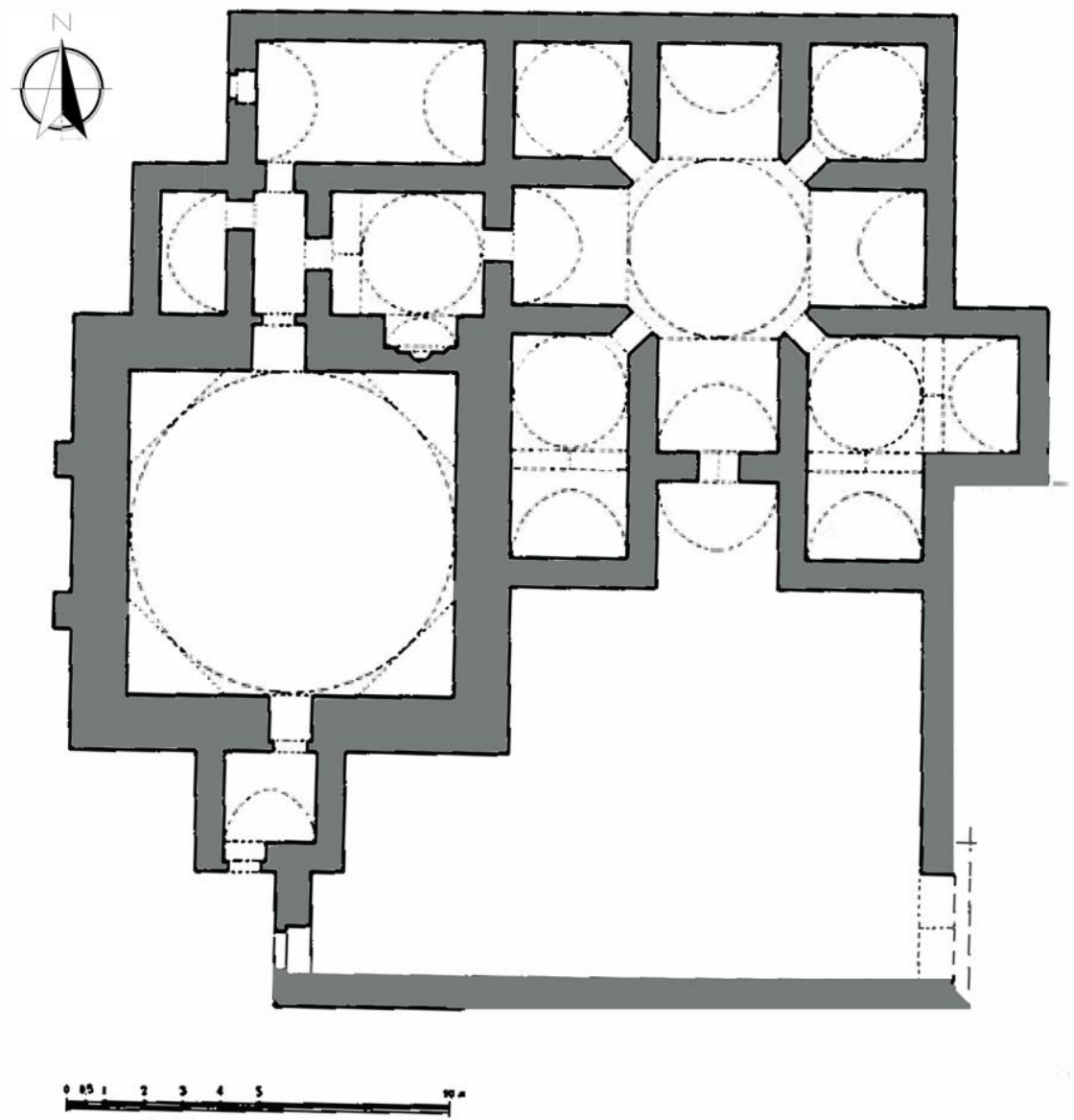

Figure 10: Plan of the hammam (Erken 1977: 147). 